Хлопова Дарья Евгеньевна

студентка

Научный руководитель

Фомичева Татьяна Леонидовна

канд. экон. наук, доцент

ФГОБУ ВО «Финансовый университет при

Правительстве Российской Федерации»

г. Москва

DOI $10.21661 / r-508606$

\title{
INFORMATIZATION OF THE PROCESS OF INDEPENDENT PREPARATION FOR THE STATE FINAL EXAMINATION (SFE)
}

Аннотация: статья посвящена информационным технологиям созданным с целью помочь студентам во время подготовки к государственным экзаменам.

Ключевые слова: электронные образовательные ресурсы, ЕГЭ, ГИА.

Abstract: this article is devoted to Information Technologies designed to help students during their preparation for the State final certification.

Keywords: electronic educational resources, SFE, USE.

The XXI century will go down in history as a period that heralded the informatization of many spheres of human activity. Taking into account modern realities of requirements, both educational process as a whole, and development of skills of selforganization of pupils in particular are being formed. Adolescents should be ready for self-education throughout life, and passing the State final certification (herein aftercalled SFE) is the first serious task that requires the ability to organize their own learning process. And modern students are assisted in this challenge by information technology.

SFE is a form of assessment of the degree and level of development of the educational program by students. ${ }^{1}$ This definition implies that every student is required to complete a program approved by the Ministry of education, regardless of his or her personal qualities. Students often reveal some topics and issues that require additional 
or re-study during the process of preparation for the passing the SFE. To overcome these problems, students use such electronic educational resources as:

1. «Unified collection of digital educational resources» (http://school-collection.edu.ru/).

2. «FIPM»(http://fipi.ru/).

3. «Russian educational portal» (http://www.school.edu.ru/).

According to surveys conducted by the all-Russian Center for Public Opinion Research, $44 \%$ of respondents aged eighteen and over prefer independent preparation for the Unified state exam (USE). $27 \%$ of them choose e-educational and free Internet resources. ${ }^{3 .}$

However, preparation for the final exams lies not only in repeating, systematizing and deepening the already gained knowledge, but also in getting acquainted with the structure of certification, its typical tasks and their variations. To cope with this task, the graduates resort to test simulators assistance. Testing itself is a way to measure the level of information proficiency of students, based on pedagogical tests. ${ }^{2}$ Computer testing allows person to assess the existing knowledge, identify topics that cause difficulties, record and analyze the results of the done work in the shortest time.

Today in the Internet space there are a lot of sites where students can independently get acquainted with all existing regulatory materials on the organization and procedure of SFE. The main sources of such documentation are such sites as:

1. Federal portal «Russian education» (http://www.edu.ru/).

2. «Official information portal of the Unified state examination» (http://ege. edu.ru/ru/).

These sites offer not only students, but also their parents and teachers to familiarize themselves with the procedure for conducting State certification, learn about the rules for filling out answer forms, get acquainted with demo versions (demos) of tasks, as well as listen to recommendations for passing the exam in all subjects, including the exam procedure and the rules for filing an appeal.

The largest number of demo versions of tasks students can find in the Open Bank of tasks of «Federal Institute of pedagogical measurements» («FIPM»). Here are stored 
tasks, which have been already encountered in the control and measurement materials (CMM) of previous years, as well as the current year's demo.

Internet portals such as «Reshuege»(https://sdamgia.ru/) «ALEXLARIN.NET» (http://alexlarin.net), «4EGE» (https://4ege.ru/) are very popular among graduates. They are aimed at providing information support to students and applicants in preparation for the exam in all areas and admission to higher education institutions. One of the main advantages of such portals is the ability to establish feedback between the student and the teacher. Site algorithms automatically generate individual tests, according to the characteristics specified by the teacher. Thus, graduates get a chance to practice solving typical tasks in the format provided by the SFE, and the teacher can monitor their progress and, if necessary, adjust the program of submission of material.

No less important part of the organization of the process of self-training is the skill of competent allocation of available time. Inefficient time management affects the working capacity and reduces the productivity of each individual student. However, not every teenager is able to independently make a clear schedule for him or herself, and here mobile applications come to his or her rescue.

One of the most convenient and popular applications is the time tracker «RescueTime». This assistant is designed to analyze the user's day, determine what takes more and less time, and organize personal daily routine. This application is suitable for those students who, in addition to school and preparation for SFE, are engaged in additional courses or other extracurricular activities.

It should be noted that SFE is not only a test of the acquired knowledge of the student, but also his or her socio-psychological stability. USE and Basic state exam (BSE) give a powerful mental and emotional pressure on the student, with which he or she must cope for the successful completion of the final certification. Lots of mobile applications are designed to solve this problem. They offer simple and effective ways to calm down and swing the other way - breathing exercises. Mobile applications are equipped with a collection of relaxing music, voice instructions and various breathing practices, which are selected individually. The last point boasts the application 
«Breathe2Relax», which asks the user to assess the degree of their stress and offers the most effective breathing exercises.

Therefore, after analyzing all the data, we can conclude that modern technical capabilities are able to provide a comfortable environment for the student in the process of preparing for the SFE. Such results give us hope that more and more graduates will demonstrate high results in State exams and, most importantly, will gain skills of competent self-organization of the learning process, which will be useful to them in later life.

\section{Список литературы}

1. Federal Law №273-FL of 29.12.2012 «On education in the Russian Federation». Chapter 6, Article 59.

2. Avanesov V.S. The Composition of test tasks. - M.: Testing Center, 2002.

3. Fomicheva T.L., Ryzhuk M.Y., Nematulloev M.M. USE in contemporary Russian education system // Innovative projects and programs in education. - 2011. №3. - Pp. 32 .

4. Школьное образование: оценка россиян [Электронный ресурс]. - Режим доступа: https://wciom.ru/index.php?id=236\&uid=9276

5. Россияне назвали главные достоинства и недостатки ЕГЭ [Электронный pecypc]. - Режим доступа: https://ria.ru/20190522/1554798581.html

6. Официальный информационный портал единого государственного экзамена [Электронный ресурс]. - Режим доступа: http://www.ege.edu.ru/ru/main/

7. Полезные сайты для подготовки к ЕГЭ [Электронный ресурс]. - Режим доступа: https:/www.ctege.info/ege-2016/poleznyie-saytyi-dlya-podgotovki-k-ege.html

8. Официальный сайт «Rescuetime» [Электронный ресурс]. - Режим доступа: https://www.rescuetime.com/

9. Учусь и работаю: 10 приложений для тайм-менеджмента [Электронный pecypc]. - Режим доступа: https://rb.ru/list/study-work-10-apps/

10. 9 мобильных приложений против стресса, тревоги и плохого настроения [Электронный ресурс]. - Режим доступа: http://www.sibmedport.ru/article/11539-mobilnyh-prilozheniy-protiv-stressa-trevogi-i-plohogo-nastroenija/ 